\title{
Education and pleasure in the early church: \\ perspectives from the East and West
}

\author{
Morwenna Ludlow and Sophie Lunn-Rockliffe
}

\section{Introduction}

In the late fourth century, Maximus, bishop of Turin, returned to his congregation after a few days' absence, probably to attend a church council. He began his sermon by promising to preach 'something richer', to 'refresh' them 'with a sweet sermon', after returning from what he memorably calls 'such a swarm of bishops'. 'That's right', Maximus continued: "I said "a swarm of bishops", since like the bee they produce delightful honey from the blossoms of divine scriptures, and whatever pertains to the medicine of souls they make by the skill of their mouth.' The arresting image of bishops working like busy bees to distil the Bible into delicious sweetness, introduces our subject: the role of pleasure in education in the late antique, post-Constantinian church. The so-called 'Fathers of the Church' sometimes appear rather austere. Ambrose, bishop of Milan in the late fourth century, counselled his fellow clergy to avoid all kinds of jokes; although at times honourable and pleasant, they were, he said, 'quite at odds with the rule of the church. ${ }^{2}$ But Christian teachers and preachers also had a lively awareness of the psychological aspects of pedagogy, and of the power of pleasure and delight to persuade, move, instruct, and even convert. In this article, we will explore the treatment of pleasure as a pedagogical tool through the lens of sermons, letters, treatises and poetry written in Latin and Greek.

In doing so, we will bring to the fore a theme which runs in and out of discussions of Christian discourse in Late Antiquity like a golden thread. Scholars have followed the Christian authors' own tendency to ponder the dangers of physical pleasures and the task of nurturing spiritual desire, attentive especially to the complex relationship between the two. The pleasure of words has been less of a scholarly focus, although there have been treatments of, for example, Gregory of Nazianzus' use of pleasure as a poetic device, the pedagogy of 'leading the soul through words' in John Chrysostom and Augustine's treatment of delightful speech in De doctrina Christiana. ${ }^{3}$ Such discussions acknowledge the influence both of classical arguments (beginning at least as early as Socrates) about the power of pleasure to persuade. They perhaps pay somewhat less attention to assumptions, common across the ancient world, about the power of poetry and music to soothe and penetrate the soul. A notable exception is Carol Harrison's absorbing treatment of the Art of Listening: although pleasure is not the dominant theme of her analysis, her work is an important perspective on pleasure as both a problematic and a positive response to Christian speech. ${ }^{4}$

\footnotetext{
${ }^{1}$ Maximus of Turin, Serm. (Sermones) 89 (tr. Boniface Ramsey (New York, 1989), 211). As Ramsey notes (348, n. 1), Maximus' apian imagery bears some resemblance to Ambrose's In hexameron 5.21, but the idea of bishops as busy bees is also found in other Latin preachers of the period: cf Augustine, Ep. (Epistulae) 109 (tr. Sr Wilfrid Parsons (Washington, D.C., 2008), 239) from Severus of Milevius, in which Severus addresses Augustine thus: 'O truly skilful bee of God, building a honeycomb filled with divine nectar...'. On Maximus, see Pauline Allen, 'Impact, influence and identity in Latin preaching. The cases of Maximus of Turin and Peter Chrysologus of Ravenna', in A. Dupont, S. Boodts, G. Partoens, J. Leemans (eds) Preaching in the Patristic Era: Sermons, Preachers and Audiences in the Latin West (Leiden, 2018), 135-58.

${ }^{2}$ Ambrose of Milan, de officiis (offic.) 1.23.102-3 (tr. Ivor J Davidson (Oxford, 2002), 177). In this, Christians shared much in common with other philosophers; for examples see David Rylaarsdam, John Chrysostom on Divine Pedagogy: The Coherence of His Theology and Preaching (Oxford, 2014), 277-78.

${ }^{3}$ See, e.g. Stratis Papaioannou, 'Gregory and the Constraint of Sameness', in Gregory of Nazianzus: Images and Reflections, ed. Jostein Børtnes and Tomas Hägg (Copenhagen, 2006), 59-81; Rylaarsdam, John Chrysostom on Divine Pedagogy, chap. 1 and 6; and (two very different examples in a large literature) Rowan D. Williams, 'Language, Reality and Desire in Augustine's De Doctrina', Journal of Literature and Theology 3, no. 2 (1989); Michael Roberts, The Jeweled Style: Poetry and Poetics in Late Antiquity (Ithaca, 1989), 125-32.

${ }^{4}$ Carol Harrison, The Art of Listening in the Early Church (Oxford, 2013); Patricia Cox Miller, The Corporeal Imagination: Signifying the Holy in Late Ancient Christianity (Philadelphia, 2009), chap. 2 and 3; Roberts, The Jeweled Style. See also, on a broader range
} 
In what follows, then, we hope to begin to draw some of these threads together, highlighting pleasure's specifically educational role and drawing out both classical and biblical themes. We will note that, while most of our authors acknowledge pleasure as a potential problem in pedagogy, it is a problem they attempt to navigate. We will sketch out various approaches to the problem and will seek to identify in them any shared understanding of the function of pleasure in education. We begin first by outlining the parameters of what we mean by 'education' in a specifically Christian late antique context.

The subjects taught by late antique bishops and others varied widely depending on their audience and context. For adult converts in the catechumenate, the programme of teaching was carefully and deliberately staged. ${ }^{5}$ As Ambrose explains in his treatise on The Mysteries, delivered to an audience of catechumens, he had up to that point addressed moral topics connected to lessons from the Old Testament; but at this point in Lent, he turned to the 'mysteries', that is, the meaning of the sacraments, a topic which was not profaned by being shared with all and any listeners, but only revealed to catechumens close to the point at which they were to be baptised at Easter. ${ }^{6}$ Another climactic point of teaching in Lent was the exposition of the creed and the Lord's prayer, whether just to catechumens or to mixed audiences, with the creed itself cast as an epitome of scripture for beginners. ${ }^{7}$ For those attending church services, the main 'teaching' moment in church was the sermon, which usually revolved around exegesis of the scriptural lessons read during the service, but which also often had distinctive moral and even polemical dimensions. Other forms of text - particularly hymnody, composed for performance within the liturgy by writers like Ephrem, Ambrose and Paulinus - also had clearly educational functions, whether expanding on the content of scripture or expounding the mysteries of faith. ${ }^{8}$ Outside the ecclesiastical context, elite and intellectually ambitious Christians could pursue private scriptural and linguistic study, either in house groups, such as the women's groups patronised by Jerome in Rome, or virtual groups made possible through the exchange of letters. They could listen to or read devotional and instructive poetry by writers like Proba, Prudentius, Sedulius and Gregory of Nazianzus. ${ }^{9}$

of authors, Ruth Webb, Ekphrasis, Imagination and Persuasion in Ancient Rhetorical Theory and Practice (Farnham, 2009), 21, 76, 99-100.

${ }^{5}$ See Everett Ferguson, 'Catechesis and initiation' in A. Kreider (ed.), The Origins of Christendom in the West (New York, 2001), 229-68, and William Harmless, Augustine and the Catechumenate (Collegeville, 2014).

${ }^{6}$ Ambrose, de mysteriis 1.1-2. Cf also Augustine, De catechizandis rudibus (catech. rud.) and Peter of Chrysologus' catechetical Serm. 56-72. In the east, catechetical works by Cyril of Jerusalem (Catechetical Lectures and Mystagogical Lectures) and John Chrysostom (Baptismal Instructions) survive.

${ }^{7}$ See the characterizations of Nicetas of Remesiana, book V of whose Instructio ad Competentes comprised an explanation of the creed, and Augustine De Fide et Symbolo I and De Symbolo ad Catechumenos 1. Christian teachers also offered explanations of the creed for more advanced audiences, particularly in polemical contexts, e.g. Rufinus of Aquileia's Commentarius in Symbolum Apostolorum, written for bishop Laurentius. For a sermon on the creed addressed to a mixed audience of baptized Christians and catechumens, see Peter Chrysologus, Serm. 62. Gregory of Nyssa wrote series of sermons on the Lord's Prayer and on the Beatitudes for a general audience.

${ }^{8}$ On Ambrose's hymnody, see Brian Dunkle, Enchantment and Creed in the Hymns of Ambrose of Milan (Oxford, 2016), with useful comparative discussion of other authors from Ephrem to Hilary and Augustine in ch. 1.

${ }^{9}$ On early Christian poetry see especially Jaś Elsner and Jesús Hernández Lobato, eds., The Poetics of Late Latin Literature (Oxford, 2017) and Karla Pollmann, The Baptized Muse: Early Christian Poetry as Cultural Authority (Oxford, 2017) especially chapters 2 and 7 for Prudentius and chapter 4 for Proba; on Proba see also e.g. Elizabeth A. Clark, 'The Virgilian Cento of Faltonia Betitia Proba', in Studia Patristica Vol 17, Pt 1 (Elmsford, NY, 1982), 412-16, Martin Bazil, '" Rem Nulli Obscuram Repetens » : Les Stratégies Intertextuelles Dans l'exorde Du « Cento Probae ॥', Graecolatina Pragensia 20 (2004): 15-25, and Sigrid Schottenius Cullhed, Proba the Prophet : The Christian Virgilian Cento of Faltonia Betitia Proba, 1st ed. (Leiden, 2015); on Prudentius see e.g. Anne-Marie Palmer, Prudentius on the Martyrs, Oxford Classical Monographs (Oxford, 2006), and Dunkle, 'Ambrosian Imitation in Sedulius and Prudentius', in ibid. Enchantment and Creed, 186-213; on Sedulius see e.g. Carl P. E Springer, The Gospel as Epic in Late Antiquity: The Paschale Carmen of Sedulius, Supplements to Vigiliae Christianae 2 (Leiden, 1988), Sedulius, The Paschal Song and Hymns, ed. Carl P. E Springer, Writings from the Greco-Roman World 35 (Atlanta, GA, 2013) and Dunkle, 'Ambrosian Imitation in Sedulius and Prudentius'; on Gregory of Nazianzus see, e.g. Neil B. McLynn, 'Among the Hellenists: Gregory and the Sophists', in Gregory of Nazianzus: Images and Reflections, ed. Jostein Børtnes and Tomas Hägg (Copenhagen, 2006); Suzanne Abrams Rebillard, 'The Autobiographical Prosopopeia of Gregory of Nazianzus', Studia Patristica XVII (2010): 123-28; Suzanne Abrams Rebillard, 'Historiography as Devotion: Poemata de Seipso', in Re-Reading Gregory of 
As well as educating their congregations, bishops were involved in the formation of other clerics in and beyond their dioceses (both their peers in the episcopate and lower orders of clergy). Thus, Gregory of Nyssa's so-called Catechetical Oration is a text teaching other clerics how to teach, with particular attention paid to how to present what is taught: since 'the same method of instruction' is not 'suitable in the case of all who approach the word', therefore 'the method of recovery must be adapted to the form of the disease.' 10

As these comments suggest, this discussion concerns in part texts composed by and for a fairly well-educated elite. The letters to fellow-clerics found in the letter collections of Ambrose, Augustine or the 'Cappadocians', for example, assume a confidently-literate audience, who could respond in kind. ${ }^{11}$ Moreover, much poetry, even if heard rather than read, assumed an audience sophisticated enough to appreciate its skill and beauty. However, as Carol Harrison has reminded us, literacy in the ancient world did not necessarily entail the ability to read confidently by oneself. ${ }^{12}$ Someone with a middling education would have had a degree of familiarity with classics by Homer or Vergil or, in a Christian context, with the most cited books of the bible, simply by repeated hearing. Theatre was a very popular and reasonably accessible medium in late antiquity and spread knowledge of certain traditional myths as well as certain stock characters. ${ }^{13}$ Finally, many of the Christian texts discussed in this article were first communicated by being spoken (sermons first preached, then written up from notes) or read out loud, and to congregations which contained those whom preachers characterized as of limited literacy. ${ }^{14}$ Consequently, one should not assume that the use of pleasure as a pedagogical tool would have been aimed just at the highly-educated elite (for example, those educated enough to compose sophisticated texts). A modestly-educated tradesman, for example, could certainly have had enough familiarity with certain texts, themes and characters to respond with pleasurable recognition when a preacher alluded to them. This is quite apart from the different question of to what extent certain kinds of sweet or pleasant style had a broad appeal: assertions that certain biblical texts could give pleasure even to children, certainly suggest that this was what various ecclesiastical writers thought, even though their belief would be difficult for us to test. ${ }^{15}$

It is very difficult to reconstruct the audience for fourth-century Christian sermons and one must concede, at least, that audiences would have differed according to context. Paulinus, writing about visitors to the shrine to saint Felix at Nola, frequently characterized them as rustics preoccupied by the rhythms of agricultural life and the rumblings of their bellies, and the 'birthday hymns' (natalicia) which he composed for this congregation to mark the annual feastday of their saint were markedly simple in their diction. ${ }^{16}$ By contrast, from what we know of aural literacy and the theatre, it is plausible to assume that the urban congregations of Ambrose, Basil and John Chrysostom, for example,

Nazianzus: Essays on History, Theology, and Culture, ed. Christopher A Beeley (Washington, D.C., 2012), 125-42; Brian Dunkle, 'Introduction', in Gregory of Nazianzus, Poems on Scripture (Crestwood, NY, 2012).

${ }^{10}$ Gregory of Nyssa, Oratio catechetica: Preface, 'The presiding ministers of the "mystery of godliness" have need of a system in their instructions, in order that the Church may be replenished by the accession of such as should be saved, through the teaching of the word of Faith being brought home to the hearing of unbelievers' (NPNF ${ }^{2} 5$ ).

${ }^{11}$ The term 'Cappadocians' conventionally designates the literary circle of Basil, his brother Gregory of Nyssa and Basil's friend, Gregory of Nazianzus (and sometimes some of their associates).

12 Harrison, The Art of Listening, especially 4.

${ }^{13}$ According to Agnieszka Kotlińska-Toma, theatre was 'the most accessible and egalitarian form of mass entertainment' in the Hellenistic period: Hellenistic Tragedy: Texts, Translations and a Critical Survey (London, 2015), 2-3, 7, 25, 28. Blake Leyerle has argued, from the style and content of John Chrysostom's preaching, that a broad section of his congregation had a familiarity with various forms of theatre: Theatrical Shows and Ascetic Lives: John Chrysostom's Attack on Spiritual Marriage (Berkeley, CA, 2001), especially 13-16, 20-21, 160.

${ }^{14}$ Nicetas of Remesiana, Instructio V.13, expressed the value of learning and explaining the creed as encapsulating the message of salvation for those who 'are unable, or too busy with their worldly affairs, to read the scriptures'.

${ }^{15}$ See further, pages $<7>$ and $<12>$.

${ }^{16}$ On Paulinus' context, see Dennis Trout, 'Christianizing the Nolan countryside: animal sacrifice at the tomb of St Felix', Journal of Early Christian Studies 3.3. (1995): 281-98; on the style and register of his poetry, see R.P.H. Green, 'Paulinus of Nola and the diction of Christian Latin poetry', Latomus 32 (1973): 79-85. 
would have included those who, whilst not a highly-educated elite, nevertheless had the kind of cultural sensibility which could respond to certain ideas and certain literary and rhetorical techniques with pleasure. ${ }^{17}$

Through letters, and through copying and disseminating treatises and even sermons, bishops sought and shared insights into the content of their teaching, and into the most effective modes of engaging with their pupils. Thus, for example, among Ambrose's extensive correspondence with other priests and bishops, we find him writing to Sabinus of Piacenza in the 390s, sending him works such as the Hexameron (his massive cycle on creation), accompanied by letters which he wrote late at night (as he emphasises, not by dictation, but in his own hand), begging Sabinus to weigh their contents and particularly to comment on their style and to flag up any 'vain flattery and persuasiveness', words which had delighted him, the author, but which were actually empty and worthless. ${ }^{18}$ In some of these contexts, writers explain a pedagogical technique which we would like to address directly in this paper: the use of pleasure.

\section{The delights of Scripture and its performance}

One of the most important subjects to be taught in and out of church was biblical exegesis. ${ }^{19}$ In the first generations of the church after Constantine it was a pedagogical priority to provide converts with clear, persuasive, and attractive explanations of the many meanings of Scripture, whether literal, historical, spiritual, allegorical, or other. For many adults converts to Christianity - especially for the well-educated - the Bible was a novel, puzzling, unwieldy, and stylistically underwhelming set of sacred texts: as Jerome remarked to Paulinus, newly made bishop of Nola, the simplicity and poor vocabulary of scripture was due either to the faults of translators, or to deliberate purpose. ${ }^{20}$ Augustine recalled how, in the period preceding his baptism, Ambrose suggested he read Isaiah, but he did not understand the opening of the book and laid it aside for when he had acquired 'more practice in the Lord's style of language. ${ }^{21}$ The regular assertions made by Christian teachers of the riches and delights of the Bible in the fourth and fifth centuries $A D$ were, therefore, not just a repetition of a widely accepted proposition, but perhaps more of a defensive strategy provoked by criticisms of the content and style of scripture. ${ }^{22}$

The imagery used to characterize Scripture was insistently nutritive: drink for the thirsty and food for the hungry. Nor was this fare merely said to be sustaining; it was also delicious. The characterization of Scripture as food and drink drew in part on sacramental notions of the word of God as bread and wine. Drawing analogies between food and text, and between their preparation and consumption, was also a long-established classical rhetorical manoeuvre, allowing the writer to appeal to his listeners' or readers' tastebuds, and transferring qualities of

\footnotetext{
${ }^{17}$ To what extent the reflections in this article apply to other contexts, especially non-urban ascetic communities, is a question which would require further research.

${ }^{18}$ Ambrose, Ep. 23.3 (tr. Mary Beyenka et al., (Washington DC, 2001), 125). Compare Gregory of Nyssa's Ep. 29, accompanying the first part of his treatise against Eunomius, asking for feedback on words he feared were written in too much anger.

${ }^{19}$ On this massive subject, see Frances Young, Biblical Exegesis and the Formation of Christian Culture (Cambridge, 1997).

20 Jerome, Ep. 53.10. Comments such as these have sometimes been taken by scholars to indicate that the Old Latin translations were simply bad; more recent research suggests that, although awkward, they were not ignorant and their style may have reflected a specific translation method: see Philip Burton, The Old Latin Gospels: A Study Of their Texts and Language (Oxford, 2000); see also Clark, Christianity and Roman Society, 83-84.

${ }^{21}$ Augustine, Confessiones (conf.) 9.v.13 (tr. Henry Chadwick (Oxford, 1991), 163). In his De Doctrina Christiana (de doctrina), Augustine wrote more positively about biblical writers than Jerome, but nonetheless acknowledged (4.6.9) that 'they used our eloquence side by side with a rather different eloquence of their own', before analysing in formal rhetorical terms two passages from II Corinthians and Amos, to demonstrate their stylistic virtues. He concluded of Paul's writing that a 'knowledgeable person' recognizes that it is the 'commata, cola and periods' of his writing, 'deployed with tasteful variety, which produces the beauty of this style, which pleases and moves even the uneducated, like a pleasant face' (4.7.13), tr. R. P. H. Green (Oxford, 1997).

${ }^{22}$ Indeed, their understanding of biblical style was often more sophisticated than their defensive remarks imply: Morwenna Ludlow, 'Christian Identity and Rhetoric about Literary Style', in Rhetoric and Religious Identity in Late Antiquity, ed. Richard Flower and Morwenna Ludlow, forthcoming (Oxford, 2020).
} 
gastronomic taste (bitterness, sweetness, and so on) on to twin literary and moral domains. ${ }^{23}$ Nicetas of Remesiana, a bishop in Dacia writing in praise of psalmody, cast the delights of singing and listening to Scripture in church in foody terms: 'Like guests at table enjoying a variety of dishes, our souls feast (literally 'are fattened', saginantur) on the rich banquet of lessons and hymns. ${ }^{24}$ Nicetas focuses on the delightfully nourishing quality of the Scriptural feast, drawing on the long-established belief that textual varietas is a hallmark of quality and enjoyment. ${ }^{25}$ For Gregory of Nyssa the 'teachings of the gospel' are like an apple (as described in the Song of Songs) which 'fattens the body and pleases the taste'. ${ }^{26}$ The singing of psalms, he says, is 'a side dish of the meal with which the nourishment of the teaching is sweetened as if with sauces'. ${ }^{27}$

As well as food for the hungry, Scripture was also drink for the thirsty. Ambrose, writing to a new bishop called Constantius, patched together a series of watery metaphors drawn from different parts of the Bible to describe scripture itself as a sea containing deep meanings, 'sweet and transparent streams' and 'cool fountains'; he praised the 'agreeable sentences' which refreshed the minds of the hearers with spiritual drink and soothed them with the

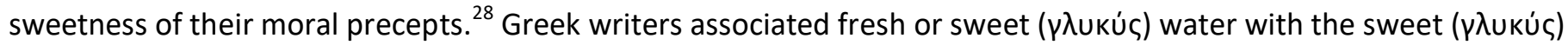
words of God. ${ }^{29}$ Thus, in one of his early letters, Gregory of Nazianzus chides Gregory of Nyssa for having given up being a reader in the church for a career in rhetoric: 'What is wrong with you ...', he complains, 'that you have thrown away those holy, thirst-quenching books you once proclaimed to the people ...? Why have you turned your hand to salty, undrinkable literature ? $^{30}$ Preaching was also regularly characterized in terms of the liquid nourishment provided through milk to infants, as a staging post on the way to more substantial and more taxing solids: Ambrose was one of many teachers to draw on the imagery of I Cor. 3.2 ('I fed you with milk, not solid food') to characterize sermons as 'milk'. ${ }^{31}$

These appeals to the spiritual senses might have been primarily metaphysical, but the notion that scripture provided pleasurable and satisfying spiritual and ethical refreshment nonetheless engaged the audience's bodies and particularly their bellies. ${ }^{32}$ For the pre-modern congregations of large cities and agricultural communities alike, the poorer of whom would have been regularly hungry and perhaps thirsty, the evocation of delicious refreshment would have been particularly tantalizing; early Christian teachers regularly acknowledged the oscillation between hunger and satiety which characterized the rhythms of pre-industrial life, and which were further heightened by Christian practices of feasting and fasting. ${ }^{33}$ Indeed, homilists repeatedly commended scripture as a delicious

\footnotetext{
23 John Bramble, Persius and the Programmatic Satire: A Study in Form and Imagery (Cambridge, 1974), 45-59; Emily Gowers, The Loaded Table: Representations of Food in Roman Literature (Oxford, 1993).

${ }^{24}$ Nicetas of Remesiana, De Utilitate Hymnorum (util. hymn.) 12 (tr. A. E Burn, Niceta of Remesiana: His Life and Works (Cambridge, 1905), 74).

${ }^{25}$ William Fitzgerald, Variety: The Life of a Roman Concept (Chicago, 2016).

${ }^{26}$ Gregory of Nyssa, hom. in Cant. 4 (tr. Richard A. Norris jr, (Atlanta, GA, 2012), 137).

${ }^{27}$ Gregory of Nyssa, in inscriptiones Psalmorum (inscr) I.III (25) (tr. Ronald E. Heine (Oxford, 1995), 92).

${ }^{28}$ Ambrose, Ep. 15.3 (tr. Beyenka, 77-8).

${ }^{29}$ See Ps. 18:10 (LXX): God's judgments are 'sweeter ( $\left.ү \lambda u \kappa u ́ \tau \varepsilon \rho \alpha\right)$ than honey'. Some modern European languages preserve the connection between fresh water and sweetness better than English: for instance French 'eau douce', German 'Süßwasser', Italian 'acqua dolce'.

${ }^{30}$ Gregory of Nazianzus, Ep. 11 (tr. Brian Daley, Gregory of Nazianzus, (London, 2006), 173). Elsewhere, he boasts that as a poet he will not 'send forth both sweet and briny water': Carmina II.1.34 ('On silence at the time of fasting') 97 (tr. Carolinne White in Gregory of Nazianzus, Autobiographical Poems (Cambridge, 1996), 173).

${ }^{31}$ Ambrose, Ep. 15.6 (tr. Beyenka, 78). On this theme as part of a broader discussion of nourishment, see John Penniman, Raised on Christian Milk: Food and the Formation of the Soul in Early Christianity (New Haven, 2017).

${ }^{32}$ See Paul Gavrilyuk and Sarah Coakley, eds, The Spiritual Senses: Perceiving God in Western Christianity (Cambridge, 2012), esp. 1-70.

${ }^{33}$ See Peter Garnsey, 'Famine and shortage', in his Famine and Food Supply in the Graeco-Roman World (Cambridge, 1988$)$, 3-7. For a medieval comparison (between the norm of scarcity and the privilege of over-eating), see Caroline Walker Bynum, Holy Feast and Holy Fast: The Religious Significance of Food to Medieval Women (Berkeley, 1988), 3-5. For allusions in sermons to the impact of feasting and fasting, see Allen, 'Impact, influence and identity', passim.
} 
spiritual feast while condemning Christians' excessive enjoyment of physical feasting and promoting the virtues of fasting, especially, but not only, in Lent. ${ }^{34} \mathrm{~A}$ similar paradox can also be seen in the erotic language of some of the patristic treatises promoting virginity.

A noteworthy aspect of these appeals to Scripture as nourishment is that they do not always apply to the parts of the Bible which are the most obviously 'pleasant' (such as the poetry of the Psalms, or the Song of Songs). In his Homilies on the Hexameron Basil revels in the sheer attractiveness of the text of Genesis:

Our discussion yesterday treated of the works of this [the first] day, and divided the narrative so as to give you food for your souls in the morning, and joy in the evening. To-day we pass on to the wonders of the second day. And here I do not wish to speak of the narrator's talent, but of the grace of Scripture, for the narrative is so naturally told that it pleases and delights all the friends of truth. It is this charm of truth which the Psalmist expresses so emphatically when he says, 'How sweet are thy words unto my taste, yea, sweeter than honey to my mouth'. ${ }^{35}$

In its appeal to the senses, the Bible was not presented as inert text to be enjoyed with the physical eyes 'on the page'; it came alive when read aloud in church and outside, pleasing by its very sound and conjuring up delightful mental images. Indeed, preachers like Ambrose and John Chrysostom emphasized the capacity of the performance of scripture to soothe, charm and instruct, all at once. 'You have heard the Apostolic voice!' Chrysostom proclaims, comparing the sound of Paul's words to a trumpet that simultaneously rouses the troops and dismays their enemy. It is also like a lyre which soothes anxieties and 'with pleasure instils into us much profit'. He attributes to Paul the literary virtues of enargeia (vividness) and varietas together with the theological virtue of bearing good spiritual fruit: Paul's words create a pleasant image in the mind's eye which has a spiritual impact.

For as in a meadow, I perceive in what has been read a great diversity of flowers; a multiplicity of roses and violets and copious fruit of the Spirit is scattered around, as well as an abundant fragrance ... . The reading of the divine Scriptures is not a meadow only, but a paradise; for the flowers here have not a mere fragrance only, but fruit too, capable of nourishing the soul. ${ }^{36}$

John Chrysostom's appreciation of Paul was not unique: Peter Chrysologus, bishop of Ravenna in the early fifth century, describes the rhythm of services as divided between three readings from, and homilies on each of Psalms, Gospel, and Paul: as he put it, the chanting of Psalms fills and delights the ear with delightfulness (dulcedine), and

\footnotetext{
${ }^{34}$ See, for example, Augustine Serm. 28 on fasting at Pentecost, comparing the words of scripture to food; idem Serm. 205E on fasting at Lent, suggesting that the word of God will sustain his congregation in spirit while they fast in body. Cf Gregory of Nazianzus contrasting the luxuries of the Christian feast of the nativity - 'the words and the divine law and the narratives' - with the luxuries of traditional Greek midwinter celebrations (or. 38:5), or Basil's severe instructions that ascetics must clear away sensuous pleasures to make way for the sweetness of Scripture (Basil, regulae fusius tractatae 6; regulae brevius tractatae 174 and 180. John David Penniman's Raised on Christian Milk: Food and the Formation of the Soul in Early Christianity (Newhaven, CN: Yale University Press, 2017) is an important study of how food was used to symbolise education and formation; he discusses the erotics present in some of this discourse (especially chapter 5 ) and the pleasure with which a child suckles at the breast (chapter 6), the pleasure of nourishment (and its implications for spiritual pedagogy) is not a major theme. For food as a symbol of pedagogy see also: Everett Ferguson, ed., 'Divine Pedagogy: Origen's Use of the Imagery of Education', in The Early Church at Work and Worship, Volume 2: Catechesis, Baptism, Eschatology, and Martyrdom (Cambridge; Eugene, OR: James Clarke \& Co; Wipf and Stock, 2014), 254-68.

${ }^{35}$ Basil, in hexameron 3.1 (in hex.)(quoting Ps 118.103 LXX). Genesis 1:1 is 'food for your souls in the morning'; Genesis 1:2-5 provides 'joy in the evening' (NPNF $\left.{ }^{2} 8\right)$.

${ }^{36}$ John Chrysostom, de statuis I.1-2, cited in George Kennedy, Greek Rhetoric under Christian Emperors (Princeton NJ, 1983), 247. In addition to being a classical motif, for Christians the lyre would evoke David soothing Saul (1 Sam. 16:14-23); fruitfulness perhaps alludes to Mt. 7:15-20. Chrysostom ingeniously attributes varietas to what others might condemn as the somewhat piecemeal structure of 1 Timothy. For enargeia and Christian adaptation of the varietas idea (applied to meadows) see Michael Roberts, The Jeweled Style, pp.39-40, 50-1 and 76 and (making the connection to paradise) Cox Miller, The Corporeal Imagination, 73-77. Ekphrasis, the bringing of a detailed scene to the mind's eye, aimed to have an emotional impact on the hearer: whether it caused pleasure or indignation, it helped to persuade: Ruth Webb, Ekphrasis, 21, 76, 99-100.
} 
similarly 'doctrine' (by which he means Paul) unfolds the mystery of the Gospel 'more pleasantly' (libentius) and 'with the greatest sweetness' (suavitate maxima). ${ }^{37}$ Peter Chrysologus was perhaps working against the grain here in promoting Paul's writings in comparative and superlative terms (as more pleasant and most sweet), since, as we will see, it was more common for preachers and teachers to emphasize the book of Psalms as the greatest repository of musical and poetic delights.

At the start of his Homily on Psalm 1, Basil emphatically defends both the usefulness and the sweetness of the Psalms. ${ }^{38}$ Although humans are distracted by pleasure (i்ovń), it is precisely pleasure which the Psalms use to redirect humans towards the good and truthful - an idea which Basil expresses with the classic analogy of 'wise physicians who, when giving the fastidious rather bitter things to drink, frequently smear the cup with honey' ${ }^{39}$ The emotional effect of the Psalms is to soothe and bring peace. In sum, the Psalter 'effaces, as far as is possible, the passions ... with a certain harmonious persuasion ( $\psi \cup \chi \alpha \gamma \omega \gamma i \alpha \varsigma)$ and pleasure ( $\dot{\eta} \delta$ ovñ $\varsigma$ ) which produces sound thoughts'..$^{40}$ The meaning of the term $\psi$ uxa $\gamma \omega$ wí $\alpha$ lies somewhere between 'persuade' and 'entertain', so it was inextricable from pleasure. In the Phaedrus Plato warns that rhetoric's power of leading the soul through words

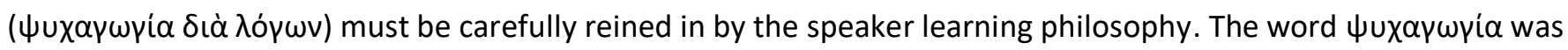
often used in tension with the truth: Basil uses it, for example, to warn against historians who make up stories to entertain their readers and, more ambivalently, for the pleasure of recalling events which were painful, but whose sting is soothed by the presence of a friend and the passage of time.$^{41}$ All the more striking, then, that he also uses $u x \alpha y \omega \gamma i \alpha$ to describe the method used by the Psalms.

Basil draws attention especially to the Psalms' use of music, a very direct means of pleasure: listeners learn 'something profitable' because, 'what enters the mind with joy and pleasure somehow becomes more firmly impressed upon $\mathrm{it}^{\prime}{ }^{42}$ In his Treatise on the Inscriptions of the Psalms, Gregory of Nyssa follows his brother's cue,

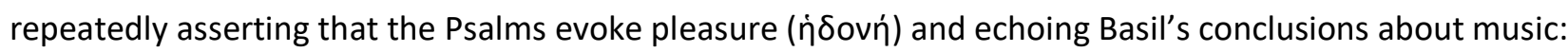

The great David combined singing with the philosophy concerning the virtues, thereby pouring the

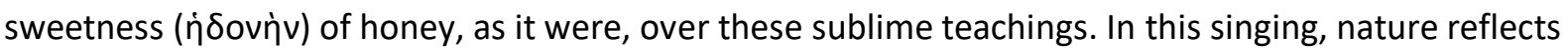
on itself in a certain manner and heals itself. ${ }^{43}$

In his commentary on Psalm I, Ambrose explained that 'while what is sung gives delight (cantatur ad delectationem), at the same time instruction is being imparted. ... [W] [Wat you will drink in with sweetness (suavitate), once it is infused into the heart, is not likely to slip away. ${ }^{44}$ That is, singing the psalms was thought to be both a pleasurable and almost stealthy way of embedding the text deeply into the singer's body, specifically into the heart, seat of cognition and emotion. ${ }^{45}$ Ambrose's commentary undoubtedly owed much to Basil's; but while Basil justified the

\footnotetext{
${ }^{37}$ Peter Chrysologus, Sermon 116 (tr. George E. Ganss (Washington DC, 2004), 194).

${ }^{38}$ On patristic traditions of commentary on psalms, see Brian Daley, 'Finding the right key: the aims and strategies of early Christian interpretation of the Psalms', in Brian Daley and Paul Kolbet, eds, The Harp of Prophecy: Early Christian Interpretation of the Psalms (Notre Dame, 2015), 11-28. Daley discusses Christian commentators' adaptation of classical ideas of the role of 'sweetness' in instruction for their exegesis of the Psalms, 14-15.

${ }^{39}$ Basil, hom in Ps. 1.1 (tr. Agnes Clare Way in Exegetic Homilies, (Washington DC, 1963), 152). On the general point see: Plato, Leges 2.659e-660a (educators use song to make good teaching pleasant, just as physicians recommend healthy food which tastes pleasant); for the 'honeyed cup' see: Lucretius, De rerum natura, 1.936-8; Themistius, or. 24:302.

${ }^{40}$ Basil, ibid.

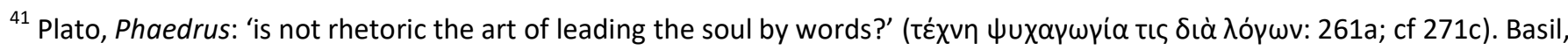
ad adolescentes (adolesc.) 4; Basil, Ep. 127.1.

${ }^{42}$ By contrast, 'a forceful lesson does not always endure': Basil, hom in Ps 1.2 (tr. Way, 153).

43 inscr I.III (23); cf inscr I.III (17) (tr. Heine, 91, 87-8).

${ }^{44}$ Ambrose, comm. Ps. 1.10 (tr. Íde Ní Riain (Dublin, 2000), 5).

${ }^{45}$ On the heart in Augustine (and its relation to classical philosophical thought), see Sarah Catherine Byers, Perception, Sensibility and Moral Motivation in Augustine: A Stoic-Platonic Synthesis (Cambridge, 2012), 35 and n. 88.
} 
pleasure of the Psalms by stressing their usefulness, Ambrose's emphasis is more insistently on their delight. ${ }^{46}$ Indeed, Ambrose invoked the value of psalm-singing for young Christians: 'Children look forward to a psalm; infants - unwilling to learn other things - delight in practising a psalm. It is a kind of game by which we learn more of doctrine than we would by formal instruction.' He concluded that 'treasured with delight (voluptate), the psalms are understood without pain or labour. ${ }^{47}$ Nicetas of Remesiana also explicitly promoted the virtues of singing hymns and psalms in church services, ${ }^{48}$ arguing that singing psalms was edifying, consoling, and pleasing to God. Sung psalms were sweet in their melody, and entered the soul because they were pleasant. Within Nicetas' treatise, there is a hint that not all of his Christian contemporaries agreed with this position, since he reports that unnamed critics (also cast as 'heretics') objected to such practices and apparently counselled silent prayer.

Nonetheless, the idea that singing was a powerful tool for teaching underpins the development and popularity of Christian hymnody - that is, of poetic texts expanding on scripture, to be chanted or sung. Christian hymns seem to have been first composed and disseminated in the Syriac east: Ephrem the Syrian composed a vast body of hymns, and disclosed in passing that he was responding to the hymnic output of the heretical Bardaisan, whose hymns are cast as disguising bitterness with sweetness, and their recipients as sick people who chose unhealthy food. ${ }^{49}$ The practice of composing and singing hymns was subsequently translated across the Roman empire, including into Ambrose's Milan: Augustine, reflecting on the period immediately after his baptism at Milan, remembered weeping during hymns and songs, moved 'by the music of the sweet chants of your Church'. His summary of how such singing 'worked' echoes Ambrose's account: 'The sounds flowed into my ears and the truth was distilled into my heart.' ${ }^{50}$

\section{The delights of expounding scripture for teachers and pupils}

In his Homilies on the Hexameron, Basil dwells on the beauties of the natural world, amassing countless details about trees, plants and animals. His discourse is beautiful, rich and varied. At the end of his eighth homily he apologises to his congregation that his sermon has been unconventionally long: he has kept them from their meal or from less innocent amusements. 'Do you love enjoyment and pleasures?' he asks: 'behold the oracles of the Lord, which, for a healthy soul, are "Sweeter than honey and the honeycomb". ${ }^{51}$ But he is also talking about the attractiveness of his preaching: 'I have still many observations to make on the products of the sea, for the admiration of my attentive audience'; 'although this honourable assembly is pleased by my speech, and the recital of the marvels of the Master is grateful to the ears of His servants, let me here bring the ship of my discourse to anchor'. He closes by recommending his audience talk about his sermon as they eat their evening meal, so that when they sleep their thoughts will still be full of the memory of his preaching and they will continue to 'enjoy the pleasure of the day' as they sleep. ${ }^{52}$

We have some, albeit scarcely unbiassed, evidence that Basil's preaching did indeed give pleasure. In his eulogy on Basil Gregory of Nazianzus emphasises that Basil's 'writings and labours' were not merely effective, but gave 'charm', 'pleasure' and 'delight', which outdid all rival attractions, secular or religious. ${ }^{53}$ Indeed, Gregory's description of reading Basil's theology can only be a description of the effects of $\psi$ uxapwyia: 'Whenever I handle his Hexameron, and take its words on my lips, I am brought into the presence of the Creator, and understand the words of creation, and admire the Creator more than before.' Basil's works, Gregory says, vividly bring bible stories to his

\footnotetext{
${ }^{46}$ Jan den Boeft, 'Delight and Imagination: Ambrose's Hymns', Vigiliae Christianae 62, no. 5 (2008): 429-30; Dunkle, Enchantment and Creed, 43.

${ }^{47}$ Ambrose, comm. Ps. 1.9 (tr. Ní Riain, 5).

${ }^{48}$ Nicetas of Remesiana, util. hymn. 1-2.

${ }^{49}$ On Ephrem's composition of hymns to counter the influence of Bardaisan's heretical hymns, see Ephrem, hymni contra haereses 53.5.1-5.

${ }^{50}$ Augustine, conf. 9.vi.14 (tr. Chadwick, 164). On Ambrose's hymnody, see Dunkle, Enchantment and Creed.

${ }^{51}$ Basil, in hex. 8.8, quoting Ps. 18.10 LXX (NPNF $\left.^{2} 8\right)$.

${ }^{52}$ Basil, in hex. 7.6 (NPNF ${ }^{2}$ 8).

${ }^{53}$ Gregory of Nazianzus, or. 43.66 (NPNF $\left.{ }^{2} 7\right)$.
} 
mind's eye; they embolden his preaching; they deepen his understanding of Scripture. Basil's stories of saints cause him to 'despise the body' and follow their example. His moral treatises 'purify soul and body, making me a temple fit for God, and an instrument struck by the Spirit, to celebrate by its strains the glory and power of God. In fact, [Basil] reduces me to harmony and order, and changes me by a Divine transformation' ${ }^{54}$ Although Gregory does not mention pleasure directly here, his words do seem calculated to prove that Basil's words amply fulfil the requirements of good Christian pedagogical writing, which Gregory defines at the beginning of the eulogy: 'To the admirers of virtue a discourse is at once a pleasure and an incentive to virtue'. ${ }^{55}$

Many preachers were anxious that, far from delighting their audiences, they were boring or off-putting. Ambrose reminded his clerical readers of the importance of getting the length and style of one's discourse just right: 'Our exposition should not be excessively lengthy, but nor should it be broken off too soon: it ought to leave behind neither a sense of distaste nor an impression of carelessness and inattention. Our language should be pure, simple, clear, and plain, full of seriousness and dignity; it should not be studied with elegance, but nor should it be bereft of a touch of appeal. ${ }^{56}$ Peter Chrysologus regularly expressed concern about his congregation's ability to tolerate the length of his sermons, and indeed postponed portions of preaching in order not to weary them. ${ }^{57}$ Augustine, in a treatise on catechizing written for a deacon of Carthage called Deogratias, sympathized with Deogratias' confession that he sometimes bored himself when he was teaching catechumens. Augustine admitted that he too was almost always displeased by his own speech; his tongue fell so short of the abilities of his mind, and the speed of his internal thought processes were slowed down by bodily enunciated words. However, Augustine noted that despite this anxiety, his words still seemed able to elicit delight (delectatio) in his audience, who thereby profited from them. He reassured Deogratias that his discourse was not as displeasing to others as it was displeasing to him, and emphasized that teachers were listened to with greater satisfaction when they themselves took joy in their work. He concluded that it was thus the duty of the one who catechized to take pleasure in his work, 'for the more he succeeds in this the more appealing [literally "sweeter" - suavior] he will be. ${ }^{, 58}$ In these introductory paragraphs, Augustine outlined a powerful psychology of the central role of pleasure in both teaching and learning. To be a good teacher, you must enjoy the content and process of what you are teaching. To learn well, you must enjoy your education.

This tallies with Augustine's own account of his conversion, written only a little earlier. When Augustine arrived at Milan as a teacher of rhetoric in 384, he was not a Christian, but a Manichee. Nonetheless, he recalls in Confessions that he went to hear Ambrose, the bishop of the city, preach. He confesses that he had no interest in the content of his sermons, but wished rather to test whether the bishop's famous oratorical skills lived up to their reputation. He recalls how, to start with, he was bored by and contemptuous of Ambrose's subject matter, but 'was delighted by the sweetness of his speech' (delectabar suavitate sermonis). He then explains that the pleasure he took in Ambrose's eloquence meant that the subject matter came to make an entry in his mind - the two could not be separated - and, in Augustine's telling, the delight he took in Ambrose's eloquent teaching thus advanced him one step further in his conversion. ${ }^{59}$ Augustine presents himself as converted as if by stealth, delighted by the beauty of Ambrose's language; this of course coincides with Ambrose's own account of the pedagogical efficacy of the beauty of Psalms, discussed above.

\footnotetext{
${ }^{54}$ Gregory of Nazianzus, or. 43.67 (NPNF $\left.{ }^{2} 7\right)$.

${ }^{55}$ Gregory of Nazianzus, or. 43.1 (NPNF ${ }^{2}$ 7).

${ }^{56}$ Ambrose, offic. 1.22.101 (tr. Davidson, 177).

${ }^{57}$ For e.g., Peter Chrysologus, Serm. 74 (tr. William B. Palardy (Washington DC, 2004), 127), finished by stating that 'in order not to be tedious, we shall explain later what our faith contains'; at the end of Serm. 96 (tr. Palardy, 156), he postponed the remainder of what he had planned to say in order that 'this work ... may be lighter for us all; ' in Serm. 122 (tr. Palardy 209), he admitted that he had previously postponed some discussion because 'weariness begets aversion'.

${ }^{58}$ Augustine, catech. rud.1-2 (tr. Raymond Canning, in Augustine, Instructing Beginners in Faith, ed. Boniface Ramsey (Hyde Park, NY, 2006), 8). On this passage, see Harmless, Augustine and the Catechumenate, 160-2. Cf Gregory of Nazianzus, or. 4.17, cited by Papaioannou, 'Gregory and the Constraint of Sameness', 68.

${ }^{59}$ Augustine, conf. V.xiii.23-xiv.24 (tr. Chadwick, 87-8).
} 
Augustine expounded the role of pleasure and delight in teaching and learning at much greater length in his De Doctrina Christiana, the first two and a half books of which were written in the period 396-7, and to which he returned in 426, finishing book 3 and adding book 4 . In the earlier phase of writing, Augustine explained how lessons that could be taught in plain statements, on topics such as membership of the Church and the life of faith, gave more pleasure if they were presented in beautiful imagery such as that in Song of Songs, although he admitted that it was unclear why this was so. ${ }^{60}$ However, by the 420 s, Augustine had developed a fuller account of the pleasures of making sense of figurative language in scripture. In a treatise against telling lies, he explained:

Those things are veiled in figures, in garments as it were, in order that they may exercise the mind of the pious inquirer, and not become cheap for being bare and obvious. Although we have learned their meaning stated openly and plainly in other places, still, when they are dug out of obscurity, they are somehow recreated in our knowledge and thus become sweet (dulcescunt). A student is not hindered because they are shrouded in this way. On the contrary, they are rendered more acceptable; for being remote they are more ardently (ardentius) desired, and for being desired they are more joyfully discovered. ${ }^{61}$

Here, Augustine built on the Ciceronian notion that metaphor, although first introduced by necessity, was developed through 'pleasure and delight' (iucunditas delectatioque), and extended Cicero's figurative language about how metaphor was a form of clothing. ${ }^{62}$ However, where Cicero had written about the invention of metaphor - like a garment first worn to keep off the cold, but then developed into adornment - Augustine was concentrating on the process of interpreting metaphor. ${ }^{63}$ Augustine's account was also, albeit implicitly, much more erotic than Cicero's: if metaphor was a way to keep meaning decent, hiding its naked form from the casual looker, then the process of understanding metaphor involved stripping those garments away, with the consequent delight of discovery described in the burning language (ardentius) of erotic love.

\section{Pleasure as a deliberate strategy in educating}

Augustine returned to his De Doctrina in 426, and added a substantial fourth book about the duties of the Christian teacher expounding scripture in which he argued that wisdom was more important than eloquence, but that eloquence also had a role in Christian instruction, using the common analogy of eloquence as a sweetness which made bitter medicine more acceptable. He made the gustatory quality of learning explicit in his assertion that 'Learning has a lot in common with eating: to cater for the dislikes of the majority even the nutrients essential to life must be made appetizing. ${ }^{64}$ Augustine then cited the famous Ciceronian maxim that the eloquent should speak to 'instruct, delight and move listeners', and stated explicitly of the second of this list that 'A hearer must be delighted so that he can be gripped and made to listen'. ${ }^{65}$

\footnotetext{
${ }^{60}$ Augustine, de doctrina 2.6.7-8 (tr. Green, 32-3).

${ }^{61}$ Augustine, contra mendacium 24 (tr. Mary Sarah Muldowney in Augustine, Treatises on Various Subjects, ed. Roy J. Deferrari (Washington DC, 2002), 154).

${ }^{62}$ Cicero, de oratore 3.155 (tr. H. Rackham and E. W. Sutton, Loeb Classical Library 349 (Cambridge MA, 2014), 121-3): “'The third method in our list, the use of metaphor, is of wide application; it sprang from necessity due to the pressure of poverty and deficiency, but it has been subsequently made popular by its agreeable and entertaining quality. For just as clothes were first invented to protect us against cold and afterwards began to be used for the sake of adornment and dignity as well, so the metaphorical employment of words was begun because of poverty, but was brought into common use for the sake of entertainment."' At this point in the dialogue, the speaker - Crassus - is making an extended comparison between the inventions of metaphor and clothing.

${ }^{63}$ Rita Copeland, Rhetoric, Hermeneutics and Translation in the Middle Ages: Academic Traditions and Vernacular Texts (Cambridge, 1991), 155-8, on Augustine re-defining the rhetorical category of inventio as a hermeneutical tool.

${ }^{64}$ Augustine, de doctrina 4.11.26 (tr. Green, 117).

${ }^{65}$ Augustine, de doctrina 4.12.27 (tr. Green, 117-8), citing Cicero, de oratore 69.
} 
Well-educated Christians like Basil and Gregory of Nazianzus had similar cultural assumptions to Augustine. If good words could instruct, delight and move, then good literature was both pleasant and useful. Most literature - with some careful interpretation - could be made useful. ${ }^{66}$ Therefore, in his advice on the education of young men, Basil compares the works of poets such as Homer and Hesiod to attractive flowers and uses the honey trope to urge his readers to engage with the texts more deeply:

For just as bees know how to extract honey from flowers which to humans are agreeable only for their fragrance and colour, even so here also those who look for something more than pleasure and enjoyment in such writers may derive profit for their souls. ${ }^{67}$

Although Basil has failed to grasp the difference between honey and nectar, his clever metaphor successfully conveys the idea that Christian readers must neither take something from every flower, nor drink everything from just one bloom. However, although the flowers of Greek literature are pleasurable and can lead the young to the 'honey' of teachings about virtue, Basil also warns about the dangers about a lack of discrimination: one must guard against the possibility that one might 'drink in poison with honey'. ${ }^{68}$

Furthermore, if all literature could be useful then poetry could have a role in Christian pedagogy, and it was not just hymns, or liturgical poetry that were acceptable. One explanation for the numerous attempts at Christian poetry in the late fourth century may have been the decree of the emperor Julian in 362 that those who taught classical texts (such as Homer) in schools should themselves uphold traditional religion, a move which was interpreted as expressing Julian's desire to keep Christians away from teaching the 'pagan' classics. ${ }^{69}$ Christians responded, it is argued, by writing their own classics, putting Christian ideas in Greek forms. ${ }^{70}$ That may be one explanation, but another explanation is staring us serious-minded scholars in the eye: perhaps Christians wrote Christian poetry because it was fun and because they thought it would give others pleasure too, all the while educating them into the bargain.

Gregory of Nazianzus' poem On his own Verses expresses this particularly clearly. After professing to eschew the temptations of fame, the poet gives four reasons for writing verse rather than prose: first, Gregory hoped that the effort of writing verse would force him to write less; secondly, he would show that Christian literature could rival that of others. ${ }^{71}$ Whilst these reasons perhaps hint at the pleasure Gregory's verse might give an audience, the next invoke pleasure specifically: not only has writing poetry consoled him in his illness, Gregory writes, but its qualities

\footnotetext{
${ }^{66}$ For Christians, this assumption turned into a belief in the 'catechetical end of all literature': Brian Dunkle, 'Introduction', in Poems on scripture, by Gregory of Nazianzus (Crestwood NY, 2012), 17.

${ }^{67}$ Basil, adolesc. 4 (tr. Frederick Morgan Padelford, Essays on the Study and Use of Poetry by Plutarch and Basil the Great (Newhaven CN, 1902) located at http://www.tertullian.org/fathers/basil litterature00.htm [accessed 6 July 2018]. Cf Gregory of Nazianzus: 'The ancients sang instruction in their verse, ' Making delight the vehicle of beauty, ' Forming the heart for virtue by a song' (carm. II.1.39 ('On his own Verses') tr. Daley, 165).

${ }^{68}$ Basil, adolesc. 4 (tr. Padelford).

${ }^{69}$ This issue has provoked much scholarly controversy. For a brief but subtle assessment see Gillian Clark, Christianity and Roman Society (Cambridge, 2004), 89-90; see also John McGuckin, St Gregory of Nazianzus: An Intellectual Biography (Crestwood NY, 2001), 117. For a challenge to the scholarly consensus, with helpful analysis of various interpretations, see Neil McLynn, 'Julian and the Christian Professors', in Being Christian in Late Antiquity: A Festschrift for Gillian Clark, ed. Carol Harrison, Caroline Humfress, and Isabella Sandwell (Oxford, 2014), 120-134.

${ }^{70}$ See e.g. Brian Dunkle, 'Introduction', to Gregory of Nazianzus, Poems on scripture, 18-20 and (more subtly) John McGuckin, '10. Gregory: The Rhetorician as Poet', in Gregory of Nazianzus: Images and Reflections, ed. Børtnes and Hägg, 212.

${ }^{71}$ Gregory of Nazianzus, carm. II.1.39 ('On his own Verses') (tr. Daley, 163-4); this poem is 'a sketched out program of Christian paideia': John McGuckin, '10. Gregory: The Rhetorician as Poet', in Jostein Børtnes and Tomas Hägg, eds, Gregory of Nazianzus: Images and Reflections (Copenhagen, 2004), 209-10. Gregory does not specify who these others are: referring to them as 'strangers' (toù §'́vous: PGxx 1333:1), he seems to be making a distinction between poets who are Christian and those who are not, but it is unclear whether he is referring to contemporary or classical works. Readers of Gregory's vast corpus of poetry might raise an eye-brow over the first reason.
} 
can attract young people to God. To press the point home Gregory blends the trope of the honeyed cup with the ancient belief in the soothing qualities of the lyre:

And of the folk who find such joy in words:

My verse could be for them a pleasant potion,

Leading them towards the Good by mild persuasion,

Sweetening by art the bitter taste of law.

Verse helps us to relax the tightened string,

If we but will, even if it be not more

Than lyric songs, musical interludes.

I write them simply, then, for your delight,

Lest other pleasures steal you from true Beauty. ${ }^{72}$

Even in his so-called Poemata arcana (poems of the mysteries), which tend towards an epic rather than a pastoral style, Gregory announces that he will 'mix a little enjoyment with my poem' ${ }^{73} \mathrm{He}$ describes with pleasing bravura the brilliance of a rainbow and the violence of a raging river, and playfully echoes Homeric tropes in his first lines: 'We shall sing first of the Son'; 'Sing also the praise of the Spirit'. ${ }^{74}$ His autobiographical works, although sometimes tending to gloomy introspection, sparkle with wit - not least, caustic remarks about his enemies. Gregory's pedagogical method is to draw the audience into the narrative through emotion, inducing his audience to respond to and with him. ${ }^{75}$ In another collection of poems Gregory plays with rhythm, acrostics and other mnemonic effects so that young believers can memorise key facts and digest key truths of the gospel. He describes this kind of poem as a 'helpful plaything for children'. ${ }^{76}$ In sum, whatever their precise theme and audience, Gregory appears to ascribe to his own poems something of the pleasant usefulness which Basil saw in the Psalms: as Neil McLynn argues, his poetry had a 'constructive' purpose and Gregory was not merely 'aiming to impress'. ${ }^{77}$

The notion that poetry was an easier medium through which to teach than prose can also be found in Latin Christian writing. Sedulius, writing in the early fifth century, produced five volumes of poetry in dactylic hexameters about Old Testament miracles and the miracles of Christ which were to prove incredibly popular. However, in stark contrast to the common homiletic presentation of scripture - and especially Psalms - as a delightful and inexhaustible feast discussed earlier, and pointedly comparing his own work to the 'splendid meals offered by noble men of learning', Sedulius Sedulius characterized his work as modest fare to the dinner guest-cum-reader, 'a few greens from a poor man's garden' ${ }^{78}$ However, in an accompanying letter to the dedicatee, a presbyter called Macedonius, Sedulius' rationale for writing in verse drew repeatedly on the pleasure principle. He was mindful of the fact that 'there are many for whom instruction in worldly letters is all the more attractive because of the delights of poetry (poeticas ... delicias) and the pleasures of verse (carminum voluptates)'. He continues: 'what they see honeyed with the allurement of verse they take up with such eagerness in their hearts that by repeating it again and again they become sure of it and store it up in the depths of their memory.' That is, poetry allures its readers into recitation and repetition, which in turn lodges it deep within. Sedulius concludes that making use of this habit might allow them to

\footnotetext{
${ }^{72}$ Gregory of Nazianzus, carm. II.1.39 (tr. Daley, 164). For the 'pleasant potion' see also Himerius, or. 16.2-19, riffing on Odyssey 4.219-32.

${ }^{73}$ Gregory of Nazianzus, poemata arcana, 7.53 (tr. D. A. Sykes (Oxford, 1997), 37).

${ }^{74}$ Ibid. 6.1-7; 27-32 (tr. Sykes, 27; 29); opening lines of poems 2 and 3, cf Iliad I:1; Odyssey I:1; Aeneid I:1. The Iliad and the Odyssey were well-known even to school-boys: these allusions are not especially erudite.

${ }^{75}$ Suzanne Abrams Rebillard analyses precisely how Gregory of Nazianzus' autobiographical poetry, which is 'universally agreed to be pedagogical', affects its audience: 'Historiography as Devotion: Poemata de Seipso', 127-28, 134, 136.

${ }^{76}$ Dunkle, 'Introduction', 22.

${ }^{77}$ Neil B. McLynn, 'Among the Hellenists: Gregory and the Sophists', 234.

${ }^{78}$ Sedulius, paschale carmen (tr. Carl P. E. Springer (Atlanta, 2013), 3).
} 
be 'won for God of their own will'. The desire to convert learned readers by re-telling the central stories of scripture in poetry is, he tells Macedonius, thus not frivolous, but appropriate. ${ }^{79}$

\section{The dangers and gains of pleasure in education}

The relationship between pleasure and persuasion, between delight and education, in patristic thought was not solely negative or positive, but rather relational. In introductory remarks to his commentary on Psalm 1, Ambrose emphasized the double-edged quality of delectatio (delight or enjoyment): 'Enjoyment of future bliss was the highest motive God put to us for the practice of virtue. Enjoyment, too, was the furious spur by which the devil plotted our downfall.' He went on to outline how God had placed Adam in paradise to enjoy eternal delight, and how he had been deceived by the serpent by means of delight. After listing some of the delights of nature, from birds singing melodiously in some lovely spot, to breast-feeding infants being caressed, he concludes that 'it belongs to our very nature to love what gives pleasure. ${ }^{80}$ So, on the one hand, there was a well-developed suspicion of elegant and persuasive language being used to move man to sin, grounded in the scriptural narrative of the fall, in which the serpent seduced the first humans through speech; this was woven together with anxieties about how false teachers, especially heretics - like Satan before them - could flatter and delight their audiences into embracing bad doctrine. But on the other hand, there was also a strong interest in how the beauty of language was connected to (albeit perhaps inadequate to describe) the beauty of God's good creation, and Christian teachers repeatedly pointed out that scripture was full of beautiful and pleasing phrases and images, and recommended that Christian teachers should make use of pleasing and sweet language in their own discourses to please, persuade and instruct their congregations. It is notable how much of the vocabulary of pleasure and delight (delectatio, dulcitudo, suavitas, voluptas in Latin, hèdonē, glukasma, terpsis, chara in Greek) has strong sensory and sensual associations with the body and its appetites - often thought to be gateways to demonic suggestion - and yet could also be deployed to spiritual ends. ${ }^{81}$

A key example of this tension can be found in Gregory of Nyssa's Homilies on the Song of Songs. In the Preface Gregory of Nyssa defends his allegorical method, which is to find spiritual edification in the attractively erotic language. There is danger, he acknowledges, in 'more fleshly folk' being led astray by the text into sensory pleasure; but really the text is about 'spiritual welfare' ${ }^{82}$ It is also emphatically about teaching: Gregory constantly refers to the bride in the Song as 'the teacher'. She is the one who is first seduced by the divine Word and then uses her own words to point the way to him. ${ }^{83}$ In Gregory's interpretation, she is rarely a soul on an introspective ascent to the divine; instead she is a symbol of the teaching role of the church and its members, she is compared to Paul or other apostles and she teaches with authority. ${ }^{84}$

Gregory's interpretation is stimulated by the fact that, like the Psalms, the Song of Songs was easy to regard as a pleasurable to read. To Gregory, trained in rhetoric, its speeches sounded like ancient encomia, speeches of praise which evoke the audience's pleasure. The divine Word is the 'herald and portraitist of [the bride's] beauty'. He declaims like a classical rhetorician, dwelling on her features in loving detail; his words of praise give pleasure

\footnotetext{
${ }^{79}$ Sedulius, epistola ad Macedonium 1 (tr. Springer, 213).

${ }^{80}$ Ambrose, comm. Ps. 1.1-2 (tr. Ní Riain, 1-2).

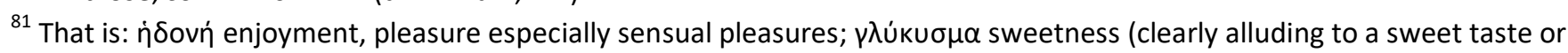

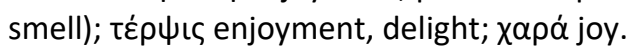

${ }^{82}$ Gregory of Nyssa, hom. in Cant., Preface (tr. Norris, 3). Although 'fruit' here 'certainly means teaching', it must be received by 'the soul that has trained its organs of sense': 4 (tr. Norris, 131).

${ }^{83}$ Teacher: ibid. 2, 4, 13, 15 (Norris, 51, 147, 399, 403, 463); pointing the way: ibid. 15 (tr. Norris 463). See: Morwenna Ludlow, 'Texts, Teachers and Pupils in the Writings of Gregory of Nyssa', in Lieve van Hoof and Peter van Nuffelen (eds) Literature And Society in the Fourth Century A.D. A Magic Stronger than the Governors' Power (Leiden, 2011), 99-102.

${ }^{84}$ Paul and the evangelists: Gregory of Nyssa, hom. in Cant., 10 (tr. Norris, 319); authority: 10 (tr. Norris 317 - in Greek, this echoes Mk 1.22 and parallels). This emphasis on the bride as teacher seems not to be a strong feature of Latin exegesis of the Psalm, to judge from Karl Shuve, The Song of Songs and the Fashioning of Identity in Early Latin Christianity (Oxford, 2016).
} 
through repeated comparison and analogy: 'Behold you are beautiful. Your eyes are like doves' ${ }^{85}$ Commenting on how the Word highlights the pleasantness of spring with certain literary techniques, Gregory concludes that he 'gives pleasure in [his] account of springtime's beauty, both casting out gloom and dwelling fondly upon accounts of things that are sweeter'. ${ }^{86}$ Not only are God's words pleasantly beneficial; so are those of the church. When Gregory describes how the bride/the church receives teachings from the groom/the Word and passes them on to others, he stresses that these teachings are sweet and should continue to give pleasure. For example, in Homily 10 the bride calls down the Holy Spirit on her garden, the members of the church, asking the Spirit to 'prepare them, as you pour out the sweet savour of the doctrines, to let sweet-smelling prophecy and the saving teachings of the faith flow freely from their mouths in every type of language' ${ }^{87}$

Gregory does not shrink totally from the association of pleasure with the body: for him, the language of sensory pleasure indicates the fact that the church can talk of Christ precisely because of the Word's incarnation in a real human body. ${ }^{88}$ Although his preface shows that he is aware of the dangers of the Song's sensory language, he clearly believes that the Song (and his interpretation of it) should render the right kind of pleasure because it has been inspired by the divine word.

Nevertheless, Gregory and his contemporaries are clearly anxious about the fact that there is a very narrow line between the appropriate and the inappropriate use of pleasure in their discourse. For example, they apologise for getting caught up in the flow of their own eloquence as if they fear they are enjoying their own words too much. ${ }^{89}$ They are anxious too about the tone of their speech: attacks on heretics could bring a kind of pleasure, but Gregory of Nyssa, for example, expresses his concern that his vituperative attacks on Eunomius went beyond the pale. ${ }^{90}$ The teacher who used humour walked an especially tricky tightrope. As we saw above, Ambrose took a generally dim view of clerical jokes. The Cappadocians certainly use amusing absurdities to refresh the congregation with a moment of pleasure and prod them to take note of what has just been said. But humour 'which lacks moderation' could also become unpleasant, as Gregory of Nazianzus points out in a passage which itself uses humour to illustrate his point:

Even in regard to sweet honey, too much and too often can make us sick. As Solomon says (and I agree with him), 'there is a season for everything'... just as a flower is quite out of season in winter, and just as man's clothing does not look right on a woman, or vice versa. Just as uproarious laughter would be seriously out of place at a funeral, or bitter tears shed at a party... ${ }^{91}$

Precisely because it brought pleasure, there was anxiety that good teaching could cross the dividing-line between edification and entertainment. John Chrysostom is famously grumpy on this count. He complains that his

${ }^{85}$ ibid. 7 (tr. Norris, 227). Gregory analyses how the groom praises the bride: 3 (tr. Norris, 89) and how the bride gives a pleasurable account of the groom: 14 (tr. Norris, 451-3).

${ }^{86}$ ibid. 5 (tr. Norris, 159).

87 ibid. 10 (tr. Norris, 319): the prophets, Paul, and the four evangelists are cited as examples of those who pass on the 'sweet savour of Christ' (ibid.). See also 14 (tr. Norris, 451): The 'sweet throat' of Song 5.16 signifies 'the servants and interpreters of the Word, in whom Christ speaks. The blessed Paul gave proof of the Christ speaking in him, and, having lent Christ his own voice, he gave voice to sweetness'.

${ }^{88}$ [The bride] leads her virgins to the theophany that came to us through the medium of the flesh.... So the bride says to them: 'My kinsman is white and ruddy... his head is as fine gold': 13 (tr. Norris, 405).

${ }^{89}$ Among countless examples: Basil, in hex. 8.8 ((NPNF $\left.{ }^{2} 8\right)$; despite declaring himself 'ashamed to see that my discourse oversteps the accustomed limits', Basil is certain he has pleased his audience; Gregory of Nazianzus, carm. II.1.39 ('On his own Verses') (tr. Daley, 163); Gregory of Nyssa, Eun III 10,45 (tr. Stuart G. Hall, in Johan Leemans and Matthieu Cassin, eds, Gregory of Nyssa, Contra Eunomium III (Leiden, 2014) 235): 'I am aware that my book is getting somewhat disorderly. It does not stay in its correct course, but like a hot and headstrong foal is being carried away...'.

${ }^{90}$ Gregory of Nyssa, Ep. 29.

${ }^{91}$ Gregory of Nazianzus, or. 27.5, quoted in John McGuckin, 'St. Gregory the Comic', in Beeley, ed, Re-Reading Gregory of Nazianzus (Washington DC, 2012), 275. Humour is of course contextual and some images seem offensive or just plain bizarre to us today, while other gentler attempts simply pass us by. 
congregation are applauding his sermons for the wrong reasons: they are childish, they are not really listening, and it encourages vanity in the preacher. On one occasion, the congregation even applauds his suggestion that they should ban applause! Notably, John identifies pleasure as the heart of the problem: 'you desire not to hear a discourse calculated to lead you to compunction, but one that may delight you from the sound and composition of the words, as though you were listening to singers and minstrels'. ${ }^{92}$ A preacher who panders to his audience, he says, is just like a parent who vainly tries to please a sick child by giving them cake and fizzy drinks, when such food will only make them sicker. John admits that he has given way to the temptation 'when we idly busy ourselves about beautiful expressions, and the composition and harmony of our sentences, in order that we may please, not profit: (when) we make it our aim to be admired, not to instruct; to delight, not prick to the heart; to be applauded and depart with praise, not to correct men's habits!'. When people applaud him, Chrysostom confesses, 'I am delighted, and give way to the pleasurable feeling'; but then he goes home and weeps, reckoning that as soon as the congregation applauded, they had forgotten what he had said. ${ }^{93}$ Augustine revealed a similar anxiety when preaching away from home at the bidding of another bishop; he explained that 'the time my satisfaction, my joy, is really solid and unalloyed is when I am listening, not when I am preaching. Then, you see, I can enjoy myself without a qualm. That pleasure has no side to it; where there is only the solid rock of truth, there's no need to fear the precipice of pride. ${ }^{94}$

\section{Conclusion}

The Christian writers we have surveyed were fully aware of the dangers of pleasant speech. Indeed, they have many negative things to say about pleasure: while we have not dwelt on them here, it is evident how concerns about pleasure affect discussions of how good speech could both educate and delight. As we have just seen, writers like Ambrose and Gregory warned against the dangers of misusing or misunderstanding delightful speech because of its connection with sensory and worldly pleasures. They were ostensibly defending Scripture itself (and, as we have seen, there was general agreement that Scripture was pleasant nourishment and sweet refreshment). But they were surely also making a space in Christian education for their own forms of sweet persuasion. Of all the prose writers we have considered, Ambrose and Gregory were perhaps the ones who were most unabashed at luxuriating in the sheer pleasure of a pedagogical language which was both sensuous and edifying. Augustine's prose often shares these qualities, but he is somewhat more careful and deliberate in his defence of delight as a literary strategy. He has a teacher's sensitivity to the need for both good, plain speech and for the kind of pleasure which rendered good argument gripping and ultimately persuasive. A related, but slightly different strategy was evident in the poets we have discussed: for them, pleasure was the justification for their choice of the elaborations of poetry over plainer prose: as both Sedulius and Nazianzus comment, 'honeyed words' make their work more attractive and thus more educational. In addition, both poets point to another pedagogical advantage: poetry pleasantly seeps into the memory, whether by encouraging repetition, or by the use of entertaining mnemonic devices.

Basil's attitude to pleasure seems somewhat cautious, weighing pleasure up against the usefulness of a text, whether it was a Psalm or one of the Greek classics. Nevertheless, we have seen how, in his Homilies on the Hexameron, he clearly delights in the process of exegesis. This is something rather different from the enjoyment of a particular literary tone; rather, the pleasure is more active, consisting in chewing a text over and digesting it. A similar pleasure in hermeneutical activity was also evident in Augustine's vivid, erotically suggestive account of 'uncovering' biblical metaphors. In addition, these writers saw teaching not only as merely conveying information or demonstrating a practice, but as a performance. This was clearly a divisive idea: Augustine actively recommends that

\footnotetext{
92 All remaining quotations in this paragraph: John Chrysostom, hom. in Ac., 30 (PG 60:225-6).

${ }^{93}$ Somewhat beyond the time-frame of our study here, the Byzantine literary critic Michael Psellos provides a vivid example of how an author could get stuck at the surface level of a text, seduced by its beauty: 'Psellos, the reader, indulges in the material pleasures of writing', using eroticised imagery to convey his pleasure. Stratis Papaioannou, Michael Psellos: Rhetoric and Authorship in Byzantium (Cambridge University Press, 2013), 96.

${ }^{94}$ Augustine, Sermon 179.3 (tr. John E Rotelle, (Charlottesville VA, 2001) and, for the effect of praise, on him, Confessions 10.36.59.
} 
Deogratias should enjoy his teaching of catechumens, for then they too will enjoy listening and learn more. On the other hand, Augustine also reveals that listening was for him a greater joy than preaching, since it kept him safe from the dangers of prideful display. John Chrysostom similarly fears the entry of pride and superficiality into his preaching (a much more public performance). If his audience claps, are they really learning? And if he enjoys preaching, is he merely enjoying their praise $?^{95}$ The ancients often distinguished between public speaking (associated with theatre and the forum) and private teaching (associated with schools and more private contexts). It is possible that in expressing anxieties about applause and praise, John Chrysostom is wondering whether one could recalibrate the Christian sermon so that it was associated less with showy public performance and more with the exposition of texts to a committed audience. Both public and private teaching could bring pleasure to the audience, but perhaps Augustine's and Chrysostom's comments suggest that there was something more dangerous in the pleasures brought by public display.

While there are clear differences in approach among the authors considered here, there seem also to be some common notions about good and bad uses of pleasure in Christian education. Good pleasure not only attracts the audience, but draws what they are learning deep into their soul. A bad use of pleasure, however - even if it is used to enhance truthful teachings - distracts the audience away from what they are meant to learn. There appears to be a distinction here between depth and superficiality: pleasure which remains on the surface is not really doing its job. This explains the popularity of gustatory metaphors in pedagogy: one needed to properly ingest and digest what one was learning. But it also raised the stakes, for a teacher of falsehood who used pleasurable words could do untold damage to a pupil's soul.

Finally, the writers we have examined here all seem fully aware of the question of pleasure in education. Whether they guarded against the overuse or misuse of pleasure, weighed it up against a text's utility, devised careful strategies for its employment or revelled in its power - in one way or another, like Paul and the Psalmist, they all used 'honeyed words'. 